\title{
Efektivitas Kepemimpinan dan Komunikasi Tim Keselamatan Pasien di RSI Ibnu Sina Pekanbaru Riau
}

\section{Leadership and Communication Effectiveness on Patient Safety Teamwork Ibnu Sina Islamic Hospital Pekanbaru Riau}

\author{
Hetty Ismainar* Andaru Dahesihdewi** Iwan Dwiprahasto***
}

\author{
*STIKes Hang Tuah Pekanbaru Riau, **RSUP Sardjito Yogyakarta, ***Graduate Program in \\ Hospital Management, Gadjah Mada University
}

\begin{abstract}
ABSTRAK
Keselamatan pasien merupakan prioritas dalam aspek pelayanan di rumah sakit. Upaya penyelenggaraannya diharapkan meminimalkan risiko Kejadian Tidak Diinginkan (KTD). Komite Keselamatan Pasien di Rumah Sakit (KKP-RS) adalah wadah yang berinisitif mengajak semua stakeholder untuk memperhatikan keselamatan pasien. Karakteristik efektivitas kinerja tim harus memiliki prinsip leadership. Berbagai penelitian tentang patient safety teamwork ini terus dilakukan dan hasilnya komunikasi juga merupakan salah satu aspek yang mempengaruhi efektivitas kinerja teamwork. Tujuan penelitian adalah untuk mengevaluasi efektivitas kepemimpinan dan komunikasi kinerja tim KP-RS di RSI Ibnu Sina Pekanbaru, Riau. Jenis penelitian ini observasional, deskriptif menggunakan mixed methods dengan rancangan sequensial eksploratory. Wawancara mendalam dan observasi digunakan untuk mengeksplorasi persepsi dan perilaku yang menggambarkan efektivitas kepemimpinan dan komunikasi pada tim KP-RS. Kemudian dilakukan survei pada 20 informan untuk mengelompokkan persepsi efektivitas kedua aspek tersebut kedalam level kompetensi YAKKUM. Pengolahan data kualitatif menggunakan open code 3.6 dan data kuantitatif dengan distribusi frekuensi. Subjek penelitian adalah keseluruhan anggota tim. Hasil Penelitian menunjukan dari 42 kasus laporan insiden, terjadi 45.22\% medication error, 2.38\% mengakibatkan kematian dan 50\% kasus tidak dilakukan analisis. Tidak ada laporan internal dan eksternal yang dilakukan oleh tim KP-RS. Evaluasi efektivitas kepemimpinan dan komunikasi masih berada pada level 2 dan 3. Kesimpulan dari penelitian adalah bahwa evaluasi efektivitas kepemimpinan dan komunikasi pada tim ini belum optimal. Fungsi, perilaku dan gaya kepemimpinan di tim KP-RS adalah passive leadership. Ronde Keselamatan Pasien (RKP), The SBAR Tools, reward and punistment adalah program yang direkomendasikan pada penelitian ini.
\end{abstract}

Kata kunci: Patient safety teamwork, kepemimpinan, komunikasi

\section{ABSTRACT}

Patient safety is a priority in hospitals services. Implementation of patient safety are expected to minimize the risk of adverse event. Committee of Patient Safety in Hospitals invite all stakeholders to be more attention on patient safety issues. However, in the process, teamwork seems not effective. Leadership is one of the characteristics that an teamwork should have. Various patient safety studies have been done and the result is communication also affects the efficiency of teamwork. This study was aimed to evaluate leadership and communication effectiveness of patient safety teamwork in Ibnu Sina Islamic Hospital, Pekanbaru, Riau. This study used a mixed method exploratory sequential design. In-depth interview and observation were used to explore perception and behavior that describe leadership and communication effectiveness on patient safety teamwork. A Survey using questionnaires were used to categorize perception of both aspects into YAKKUM competency level. Data were analyzed qualitatively using open code 3.6 and quantitatively through frequency distribution. All member of patient safety team participated in the study. The results of study, Of the 42 cases reported incidents, there were $45.22 \%$ medication error cases, in which $2.38 \%$ result in death and $50 \%$ were not analyzed. There were no reports of internal and external work done by team. The effectiveness of leadership and communication still at level $2^{\text {nd }}$ and $3^{\text {rd }}$. The Conclusion of the research was leadership and communication effectiveness on this team is not optimal and predominantly used passive leadership. Round of Patient Safety (RPS), The SBAR Tools, reward and punishment are recommended in this study.

Keywords: patient safety teamwork, leadership, communication.

\section{PENDAHULUAN}

Komite Keselamatan Pasien Rumah Sakit (KKP-RS) dibentuk oleh PERSI (Perhimpunan Rumah Sakit Seluruh Indonesia). Kepedulian pemerintah terhadap keselamatan pasien sangat tinggi. PERSI berinisiatif mengajak semua stakeholder untuk memperhatikan keselamatan pasien. Hal yang melatarbelakangi terbentuknya KKP-RS ini bermula dari laporan Institute of Medicine, Amerika Serikat tahun 2000, To err of human, Building a safer health system menyatakan sekitar 3-16\% pelayanan pasien. 
Menurut laporan dari IOM (1999); To err is human, building a safer health system, di Amerika Serikat diproyeksikan terjadi 44.000 sampai dengan 98.000 kematian setiap tahun akibat dari medical error yang sebenarnya dapat dicegah. Angka ini hampir empat kali lipat dari kematian akibat kecelakaan lalu lintas. Berbagai studi banyak menggambarkan besarnya masalah medical error yang ada disekitar sistem pelayanan kesehatan yang ada.

Keselamatan pasien sudah merupakan prioritas dalam aspek pelayanan dan sudah menjadi tuntutan kebutuhan dalam pelayanan kesehatan. Upaya penyelenggaraan patient safety diharapkan dapat meminimalkan risiko kejadian KTD. Di Indonesia sampai saat ini belum ada data yang pasti berapa sebenarnya angka KTD di rumah sakit, namun di lain pihak terjadi peningkatan tuduhan malpraktek. Hal ini membuktikan bahwa angka KTD dan near miss tersebut masih ada namun dalam proses pencatatannya tidak terdokumentasi dengan baik.

RSI Ibnu Sina Pekanbaru, Riau adalah salah satu rumah sakit swasta keagamaan kelas $\mathrm{C}$ dengan kapasitas 144 Tempat Tidur. Telah memiliki tim KPRS sejak April 2009 dengan keanggotaan 29 orang. Salah satu karakteristik efektivitas tim harus memiliki prinsip kepemimpinan (leadership) dan tim membutuhkan seorang pemimpin yang dapat menggerakkan anggotanya.

Keberhasilan kepemimpinan ditentukan oleh kemampuan mengendalikan sejumlah orang di dalam tim. Setiap anggota di dalam tim mendapatkan kesempatan yang luas dan selalu terdorong untuk berpartisipasi secara maksimal. Didalam tim seorang pemimpin harus tahu memanfaatkan anggota yang memiliki kemampuan berfikir untuk mendapatkan masukan, mampu pula memanfaatkan orang lain dalam rangka mensukseskan kepemimpinannya.

Penelitian yang dilakukan di Rumahsakit Ontario, Canada tentang hubungan kepemimpinan dan program patient safety menyatakan bahwa leadership dapat merubah sikap dan prilaku karyawan dan komitmen organisasi terhadap proses keselamatan pasien di rumahsakit. Penelitian lain dilakukan pada 154 dokter di Bahrain tentang kompetensi kepemimpinan mengatakan hanya 10\% dokter yang memiliki sertifikasi kepemimpinan formal dan $40 \%$ mengikuti pelatihan manajerial, sisanya sama sekali tidak memiliki keduanya. Hal ini dapat diasumsikan bahwa pelatihan dan kompetensi kepemimpinan dalam pelayanan kesehatan sudah diabaikan. Perilaku tim dan keterlibatan kepemimpinan mengatakan bahwa keterlibatan kepemimpinan secara tidak langsung dapat mengurangi error dalam pelayanan kesehatan tetapi komunikasi juga merupakan unsur terpenting yang dapat mengurangi hambatan dalam peningkatan kinerja tim, tanpa ada diskusi dan komunikasi antara anggota tim maka kendala yang dihadapi tim dapat terpecahkan.

Berdasarkan laporan Joint Commission on Accreditation of Healthcare Organizations (JCAHO), dari evaluasi 2840 kasus sentinel event (kejadian tidak diharapkan dan berakibat fatal) disimpulkan bahwa $65 \%$ akar penyebab masalah tersebut adalah komunikasi dan $75 \%$ dari kasus-kasus tersebut mengakibatkan pasien meninggal. Kegagalan komunikasi memberi pengaruh besar terjadinya adverse event dan mutu pelayanan. Komunikasi yang dilakukan di lingkungan kerja dapat menciptakan kepuasan teamwork meningkatkan mutu pelayanan dan keselamatan pasien di rumah sakit. Beberapa kejadian dan efek yang ditimbulkan dari masalah Kejadian Tidak Diinginkan (KTD) yang terjadi di Colorado terjadi $2,9 \%$ dan $6,6 \%$ meninggal, di New York KTD Sebesar 3,7\%, angka kematian 13,6\%. Tidak sedikit biaya yang dikeluarkan untuk KTD ini yaitu Sekitar $£ 2000$ juta per tahun, ganti rugi diklaim ke National Health Service mendekati angka $£ 400$ juta per tahunnya ditambah biaya $£ 2400$ juta sebagai biaya lainnya. Tujuan penelitian adalah untuk mengevaluasi efektivitas kepemimpinan dan komunikasi tim KP-RS di RSI Ibnu Sina Pekanbaru, Riau.

\section{METODE}

Penelitian ini dilakukan di RSI Ibnu Sina Pekanbaru Riau, jenis penelitian observasional, deskriptif menggunakan mixed methods dengan rancangan sequensial eksploratory yaitu mengembangkan hasil dari satu metode lalu menggunakan metode yang lain secara berurutan yang dimulai dengan menggali secara kualitatif terlebih dahulu kemudian dilanjutkan secara kuantitatif. Unit analisis pada penelitian ini adalah tim KP-RS. Pengumpulan data untuk penelitian kualitatif dilakukan dengan wawancara mendalam (indept interview) sebanyak 13 informan. Jumlah informan tersebut diperoleh dari analisis data sekunder dengan cara menelusuri keaktifan anggota Tim KP-RS dalam menjalankan kegiatan seperti: daftar hadir dan notulen rapat Tim KP-RS. Peneliti juga melakukan observasi partisipatif untuk melihat efektivitas kepemimpinan dengan menggunakan lembaran observasi berupa ceklist. Pengumpulan data untuk penelitian kuantitatif berupa kuisioner diberikan kepada 20 informan digunakan untuk mengelompokkan persepsi anggota terhadap kepemimpinan dan komunikasi didalam tim KP-RS dengan menggunakan standar kompetensi SDM oleh YAKKUM level 1-5 (poor, marginal, acceptable, good and excellent). Analisa data kualitatif yang didapatkan dari indept interview akan dibuatkan transkrip yang disusun dalam bentuk narasi. Dari transkrip tersebut dibuat coding, category dan menentukan tema menggunakan analisis open code 3.6.Untuk data kuantitatif berupa kuisioner, 
pengolahan data dilakukan dengan analisis distribusi frekuensi.

\section{HASIL}

\section{Patient Safety Teamwork}

Tim KP-RS (Keselamatan Pasien Rumah Sakit) Ibnu Sina Pekanbaru dibentuk pada tahun 2009 dengan jumlah keanggotaan 29 orang, anggota yang aktif berjumlah 21 orang dan yang rutin hadir dalam setiap kegiatan Tim KP-RS berjumlah 13 orang.

Berdasarkan data yang diperoleh pencatatan laporan insiden dari tahun 2009- 2011 Tim KP-RS Ibnu Sina terjadi $45.22 \%$ medication error. Terjadi pengulangan beberapa insiden antara lain: (1) Kejadian kesalahan nama obat, rupa dan ucapan mirip terjadi pengulangan sebanyak 4 kali pada tahun 2009 dan terjadi lagi di tahun 2011, (2) terjadi error akibat kesalahan identitas pasien sebanyak 7 kali pada tahun 2009, (3) kejadian salah sisi dalam tindakan terjadi 2 kali pada tahun 2009, (4) terjadi error pada monitoring cairan elektrolit sebanyak 2 kali, (5) terjadi error pada akurasi pemberian dosis obat sebanyak 3 kali pada tahun 2009.

Diawal terbentuk Tim KP-RS ini pada tahun 2009 pencatatan dan pelaporan terdokumentasi dengan baik yaitu 39 kasus, tetapi di tahun 2010 ( 2 kasus) dan 2011 hanya 1 kasus. Berdasarkan wawancara dengan informan didapatkan fakta ada ketakutan karyawan dalam proses pelaporan dan pencacatan insiden di rumah sakit sehingga insiden tersebut under report (tidak terlaporkan).

Kepedulian Tim KP-RS terhadap insiden yang terjadi sudah terlihat, beberapa kebijakan yang diberlakukan untuk mengantisipasi dan mengurangi error yang terjadi dibagian medication error adalah penempatan satu orang petugas asisten apoteker di ruangan rawat inap tertentu meskipun belum bisa diberlakukan menyeluruh disetiap ruangan rawat inap.

Keanggotaan tim KP-RS ini terbentuk dengan berbagai kriteria. Untuk ketua dan wakil adalah seorang dokter yang telah lama bekerja di rumah sakit, pernah mengikuti workshop patient safety yang diadakan oleh KKP-RS selama 32 jam. Untuk sistem pelaporan insiden di RSI Ibnu Sina hanya sampai pada tim KP-RS saja, sedangkan untuk pelaporan eksternal ke PERSI dan KKP-RS pusat belum dilakukan dan untuk laporan tahunan tim KP-RS tidak ada dokumen dan risalah rapat yang diarsipkan secara lengkap.

\section{Kepemimpinan}

Kemampuan untuk memimpin tim adalah sebuah kualitas fundamental yang dicari sebuah organisasi. Efektivitas kepemimpinan dalam tim dapat dinilai dari berbagai aspek antara lain: (1) Mampu menajamkan pikiran, menyusun misi, visi dan tujuan yang ingin dicapai, (2). Menyusun rencana aksi yang tertulis, rencana disusun disertai dengan deadline sehingga tim memiliki arah dan tujuan yang jelas, (3) Membangkitkan hasrat dan semangat yang murni dan penuh daya gerak untuk mencapai sasaran pribadi dan tim,(4) Mengembangkan rasa percaya diri dan kepercayaan, rasa percaya terhadap anggota tim dibangun, bertumbuh dengan cepat saat pimpinan membagikan pengalaman dan pengetahuannya, (5) Memupuk komitmen dan tanggung jawab, perwujudan upaya tanpa henti, perhatian yang terkendali dan energi yang terkonsentrasi, (6) Mampu menarik, memberdayakan dan memiliki anggota yang loyal, (7) Senantiasa menjadi teladan anggota tim dan (8). Berani mengambil keputusan dan bertanggungjawab terhadap keputusan. Oberservasi partisipatif yang dilakukan selama penelitian dengan menggunakan tabel cek list, terlihat bahwa kepemimpinan Tim KPRS berada dilevel 1 (poor) yaitu tidak melakukan dan level 2 (marginal) yaitu hanya melakukan sebagian saja.

Pada indept interview penilaian fungsi kepemimpinan menggambarkan sikap mengarahkan anggota, memberi masukan, memiliki perhatian, sharing ilmu serta mensosialisasikan tentang patient safety masih dipersepsikan informan pada level 2 (marginal) dan 3 (acceptable). Hal ini dapat dilihat dari kutipan wawancara berikut ini:

\footnotetext{
“...biasanya ketua.. memberikan pengarahan dalam rapat, kalau perlu protap (Prosedur Tetap).dibuat. dikaji ulang protap itu gitu." (Informan 1)

"yaa...kadang ada masukan... mm.. ya gitu.. tapi karena biasanya masalah patient safety ini lebih banyak ke keperawatan aja" (Informan 2)

"punya perhatian itu.. didukung semua pihak, sudah terlihat ya... yang akan perfect pastinya belum... "(Informan 4)

"sharing ilmu.diarahkan tapi yaach mungkin belum maksimal" (Informan 7)
}

Berdasarkan hasil indept interview tersebut diperoleh 49 persepsi Tim KP-RS guna mengevaluasi efektivitas kepemimpinan yang selanjutnya dijabarkan dalam kuisioner. Penilaian fungsi kepemimpinan menggambarkan sikap mengarahkan anggota, memberi masukan, memiliki perhatian, sharing ilmu serta mensosialisasikan tentang patient safety. Ada beberapa anggota tim yang mengatakan masukan, arahan yang diberikan belum dilakukan berkelanjutan. Akhir-akhir ini kecenderungan fungsi, perilaku dan gaya kepemimpinan tidak berjalan. Berdasarkan hasil observasi peneliti dari notulen rapat hanya 6 kali dilakukan rapat selama 2 tahun tim ini terbentuk. Evaluasi setiap hasil rapat tersebut tidak dilakukan secara berkelanjutan. Sehingga kejadian medical error terjadi berulang antara 2-4 kali terhadap kasus yang sama.

Efektivitas perilaku kepemimpinan Tim dapat dilihat dari: (1) Perilaku yang berorientasi pada tugas dan memandu anggota dalam menetapkan sasaran kinerja yang tinggi tetapi realistis, (2) Perilaku yang 
berorientasi hubungan dan memperlihatkan kepercayaan, bertindak ramah, perhatian dan memahami anggota, (3) Kepemimpinan yang partisipatif guna memudahkan partisipasi anggota dalam pengambilan keputusan, memperbaiki komunikasi, mendorong kerjasama dan memudahkan pemecahan konflik. Indept interview yang dilakukan dapat dilihat dari kutipan berikut ini:

“...entah kadang pertemuan itu tidak menarik, pemicunya tak ada, penggeraknyalah.. pokoknya malas-malasanlah tugas pokok... ga tahu, buat laporan aja" (Informan 1,)

“...yaa.. tapi realisasi dari visi dan misi itu ndak jalan, kadang kita juga perlu dorongan yaa.. dari pimpinan" (Informan 7)

“...karena jumlah anggotanya banyak yaa, kasi jobless yang jelas.. nama di Surat Keputusan (SK) ditulis.. biar ada tanggungjawab,konsekuen lah..terjun langsung ga ada, ga rutin.. kebetulan aja kayaknya" (Informan 2)

Berdasarkan kuisioner data kuantitatif terlihat bahwa perilaku, fungsi dan gaya kepemimpinan Tim KP-RS berada di level 2 (marginal) yaitu hanya melakukan sebagian saja dan level 3 (acceptable) yaitu sudah melakukan tetapi belum menjadi kebiasaan.

\section{Komunikasi}

Efektivitas komunikasi tim dapat dilihat dari aspek fungsi komunikasi tersebut yaitu: (1) berfungsi untuk mengotrol perilaku anggota dalam berbagai cara seperti mengkomunikasikan keluhan tentang pekerjaan kepada pimpinan, (2) memelihara motivasi dan menjelaskan apa yang dikerjakan untuk meningkatkan prestasi kerja, (3) Fungsi ekspresi emosi, yaitu: memberikan pelepasan ketegangan untuk ekspresi emosional dan pemenuhan kebutuhan, (4) Fungsi informasi yang dibutuhkan dalam pengambilan keputusan tim. Tipologi komunikasi tim KP-RS di RSI Ibnu Sina ini adalah adanya kecenderungan penurunan aktivitas tim sehingga komunikasi antar anggota tim yang lainnya justru bersifat situasional saja. Awal tim KP-RS terbentuk, setiap anggota rutin mengadakan pertemuan membahas kasus-kasus yang ada, seiring waktu berjalan dan kesibukan aktivitas anggota, keterlibatan anggota bersifat personal dalam menyelesaikan permasalahan tersebut.

Komunikasi menjadi unsur terpenting yang tidak dapat dipisahkan dalam sebuah teamwork. Komunikasi merupakan suatu proses, suatu kegiatan. Walaupun kita mungkin membicarakan komunikasi seakan-akan ini merupakan suatu yang statis, yang diam, komunikasi tidak pernah seperti itu. Kemampuan berkomunikasi secara efektif pada penelitian ini masih berada pada level 2 dan 3 .

Hasil indept interview yang dilakukan kepada 13 informan, memiliki persepsi yang sama. Keterlibatan anggota dalam penyelesaian masalah KTD hanya bersifat individual saja sesuai dengan tempat kejadian. Ada kecenderungan komunikasi yang terjadi diantara internal tim sudah jarang dilakukan. Tidak adanya pertemuan atau rapat yang menjadi tempat berkumpulnya anggota menjadi alasan mengapa aktifitas tim KP-RS ini akhir-akhir ini menurun. Apabila terjadi permasalahan biasanya dibicarakan pada saat morning report setiap harinya. Berikut kutipan dari informan:

\footnotetext{
“...oo tak dilibatkan semua.. ga tahu menjaga apa.. mana yang bermasalah, yaach itu aja yang menyelesaikan.. ga tau penyelesaian masalahnya"(Informan 1)

“...Kalau komunikasi yaa.. ada lah yaa.. koordinasi dari keperawatan..kita juga sudah tahu alur pelaporannya.. yaa. ga ada masalah lah..." (Informan 3)

“...karena kesibukan.. apa yaa.. pergantian direktur, tidak ada lagi, sudah lama. sudah kita ingatkan..” (Informan 7)

“...Semua harus ada protap, beberapa tahun terakhir keluar dari jalur, perbaikan tidak tertulis, kebijakan tidak jelas, lisan aja..." (Informan 8)
}

Berdasarkan hasil kuisioner, komunikasi dalam tim masih berada pada level 2 (marginal) yaitu hanya melakukan sebagian saja dan level 3 (acceptable) yaitu sudah melakukan tetapi belum menjadi kebiasaan.

\section{PEMBAHASAN}

\section{Patient Safety Teamwork}

Pada proses awal terbentuknya tim ini, keanggotaan terdiri dari 29 orang, jumlah yang terlalu banyak dan peran dan fungsi keanggotaan yang belum terstruktur jelas. Team size yang lebih besar mengakibatkan kepuasan anggota berkurang, anggota kurang berpartisipasi dan kurang bekerjasama daripada anggota tim yang lebih kecil, peningkatan ukuran tim mengakibatkan jarak psikologis antara individu. Secara umum, tim yang efektif memiliki kurang dari 10 anggota. Ketika suatu tim terlalu banyak anggota, pertimbangkan untuk memecah tim tersebut menjadi subtim.

Kompetensi dan kemampuan teamwork harus dipertimbangkan untuk menyelesaikan tugas-tugasnya. Kompetensi dan kemampuan dapat dikembangkan dengan pelatihan. Bukti-bukti ilmiah memperlihatkan bahwa kerjasama tim dapat meningkatkan mutu dan keselamatan pasien. Penelitian yang dilakukan oleh Profesor Benyamin P., kepala bagian kebidanan dan kandungan di Beth Israel Deaconness Medical Center mengatakan klaim malpraktik menurun $50 \%$ dalam 3 tahun terakhir setelah tim di unitnya mendapatkan pelatihan bekerjasama secara tim.

Dalam penelitian Gardner, et al., (2008), yang melakukan interview pada 50 orang perawat di New Zealand, mengatakan bahwa kompetensi dan kemampuan harus dipertimbangkan dalam memahami peran kompleks dari praktisi perawat. Dimensi kemampuan perlu dipertimbangkan dalam pendidikan dan evaluasi praktisi seorang perawat. Pada penelitian ini, merekomendasikan bahwa kompetensi dan kemampuan perawat harus dikembangkan, dilatih dan 
dievaluasi.

Penelitian lain di RS Bethesda Yokyakarta, penelitian ini bertujuan menyusun leadership competency. Ada 8 kompetensi kepemimpinan yang dikembangkan menurut Harvard University (2008). Perilaku 3 level manajerial, dari 131 informan tersebut hasilnya teridentifikasi masih banyak informan memiliki kompetensi berada di level 1-3. Hal ini mengisyaratkan agar kompetensi kepemimpinan di RS Bethesda ini masih pada level bawah dan harus terus dikembangkan melalui pelatihan-pelatihan.

Tim yang efektif mensyaratkan setiap anggota tim memiliki kemauan atau motivasi dan bertanggungjawab untuk menciptakan lingkungan kerja yang kondusif. Motivasi merupakan sesuatu yang memberi energi dan mengarahkan perilaku untuk secara gigih mencapai tujuan. Bangunlah kebersamaan dan loyalitas yang kuat antar anggota tim kerja. Kebersamaan dan loyalitas dapat diartikan sebagai kedekatan dan rasa kepemilikan terhadap setiap anggota tim kerja atau terhadap tim kerja itu sendiri. Kebersamaan akan sangat bermanfaat dalam teamwork. Sedangkan financing reward tidak otomatis meningkatkan kinerja tim. Proses dan penciptaan identifikasi pekerjaan yang jelas, lingkungan kerja yang baik akan dapat memotivasi anggota tim dan meningkatkan kinerja tim. Hal ini berbeda dengan penelitian yang dilakukan pada karyawan di Dinas Kesehatan Papua. Dari 211 informan, 41,4\% menyatakan kurang puas terhadap insentif yang diberikan. Mereka beranggapan semakin tinggi pemberian insentif dalam bentuk uang maka semakin tinggi kepuasan karyawan. Artinya Karyawan membutuhkan sisi financing reward untuk memenuhi kebutuhan dasar mereka seperti sandang, pangan dan papan. Bagi mayoritas karyawan, uang masih tetap merupakan motivator kuat bahkan paling kuat. Sedangkan pada penelitian ini, financing reward dari jawaban informan belum menjadi faktor utama yang harus dipenuhi.

Apabila kita berbicara tentang efektivitas tim, unsur yang mendasar sebaiknya kita harus memiliki rasa percaya diri dalam individu tim tersebut. Bila kita yakin akan berhasil maka kita dapat menyebutnya efektivitas tim, karena keyakinan menghasilkan keberhasilan. Tetapi komitmen dan dukungan sebuah pihak dalam organisasi merupakan indikator yang tidak kalah penting.

\section{Kepemimpinan}

Berdasarkan hasi penelitian ini terlihat bahwa kepemimpinan Tim KP-RS berada pada level 2 dan 3. Hal ini mengindikasikan bahwa kepemimpinan pada Tim KP-RS belum berjalan baik. Hal ini sejalan dengan penelitian yang dilakukan di Armed Forces' Hospitals Turki, Ada 5 gaya kepemimpinan yang dicantumkan dalam kuisioner yang diberikan. Dari 142 informan, $72 \%$ informan menyukai tipe kepemimpinan pasif (passive Leadership) yaitu: pemimpin hanya sedikit melakukan usaha dan hanya berada pada posisinya guna mencapai tujuan organisasi. Pada penelitian ini, terlihat tidak ada upaya anggota untuk memperbaiki dan meningkatkan efektivitas kinerja tim ini. Kesibukan pimpinan selalu menjadi alasan anggota untuk tidak respon terhadap tim KP-RS ini.

Menurut Journal of Nursing Management yang dilakukan di Inggris pada perawat di Unit Gawat Darurat. Menilai pengembangan keterampilan kepemimpinan, menggunakan kuisioner skala 1-7. Dari penelitian ini direkomendasikan bahwa karakteristik seorang pemimpin harus memiliki komunikasi yang baik, mampu mengambil suatu keputusan tepat, mampu mengelola risiko, memiliki tujuan yang jelas dan mampu mengendalikan emosi.

Penelitian lain membuktikan bahwa terjadi peningkatan yang signifikan setelah informan mendapatkan pelatihan pengembangan kompetensi kepemimpinan selama 3 hari dan dinilai setelah 3 bulan sejak pelatihan diberikan. Dengan menggunakan pendekatan berbasis kompetensi kepemimpinan, dapat mengidentifikasi, mengembangkan pemimpin yang lebih baik untuk generasi selanjutnya. Hal ini bertolak belakang dari hasil penelitian pada Tim KP-RS di RSI Ibnu Sina, tidak dilakukannya pengembangan kepemimpinan, baik dari hal fungsi, perilaku dan gaya kepemimpinan.

\section{Komunikasi}

Berdasarkan hasi penelitian ini terlihat bahwa komunikasi Tim KP-RS berada pada level 2 dan 3 dan dari observasi tabel cek list hanya berada pada level 1(poor) dan 2 (marginal). Dari penelitian yang berbeda terkait dengan unsur komunikasi, sebuah penelitian yang dilakukan di empat rumahsakit, observasi dilakukan dengan menggunakan rekaman video di 3 lokasi yang berbeda. Lokasi pertama pada ruangan saat awal perawat bertemu, lokasi kedua di ruangan pemeriksaan, lokasi ketiga diruangan sampai pasien dipanggil untuk masuk ke ruang operasi. Hasilnya 46\%-67\% perawat tidak menerapkan SBAR communication

Sama halnya sebuah komunikasi dalam tim, efek penerapan komunikasi yang baik dapat meningkatkan hubungan antar pimpinan dan anggota. Luangkan waktu untuk membangun sebuah hubungan dengan tetap berkomitmen dengan kualitas pelayanan, biasanya situasi ini akan dapat lebih bertahan dan menghasilkan good marketing relationship.

Berdasarkan analisis laporan insiden tim KP-RS di temukan dua kasus yang perlu menerapkan komunikasi menciptakan relationship marketing, yaitu: (1) keluarga pasien minta pindah ke rumah sakit lain karena pada saat anak pasien tersebut demam tinggi, dokter yang merawat tidak di hubungi, (2) keluarga pasien meminta penjelasan terhadap hasil rontgen yang telah dilakukan karena harus di ulang 
kembali. Pada dua kasus ini terlihat ketidakpuasan pelanggan. Bila komunikasi antara pasien, keluarga, tenaga medis berjalan baik, tentu hal seperti ini tidak terjadi. Disinilah kesempatan pihak rumah sakit membuktikan pelayanan terbaik kepada pelanggan.

Customer Bonding sebagai strategi baru untuk mengikat pelanggan kepada suatu perusahaan. Strategi ini bisa diterapkan pada pelayanan di rumah sakit. Pada prinsipnya proses customer bonding ini berpusat pada kesetiaan pelanggan, penampilan jujur terhadap pelanggan dan mengevaluasi kepuasan pelanggan sesuai harapan pelanggan. Sebuah sistem yang berinisiatif mempertahankan hubungan dengan setiap pelanggan atau calon pelanggan. Pada dasarnya customer bonding merupakan proses membangun dan mempertahankan kepercayaan pelanggannya, sehingga dalam hubungan tersebut kedua belah pihak saling percaya. Bila penerapan komunikasi tim KP-RS dapat dilakukan secara efektive tentunya medical error yang ditemukan pada penelitian ini tidak akan terjadi.

\section{KESIMPULAN}

Kepemimpinan tim KP-RS dalam menjalankan program patient safety di RSI Ibnu Sina Pekanbaru Riau belum optimal. Gaya kepemimpinan tim adalah passive leadership, tetapi kepemimpinan yang seperti ini justru disukai oleh anggota. Proses komunikasi tim juga belum efektif, tipologi komunikasi memiliki kecenderungan menurun sehingga KTD yang diakibatkan oleh communication failure masih terjadi. Persepsi anggota terhadap kepemimpinan dan komunikasi masih berada pada level 2 (marginal) dan 3 (acceptable) yaitu sikap melakukan sebagian tindakan dan belum menjadi kebiasaan.

\section{SARAN}

Perlu penerapan program Ronde Keselamatan Pasien (RKP) sebagai bentuk komitmen dan partisipasi manajemen rumahsakit dan tim KP-RS dalam mendeklarasikan Gerakan Keselamatan Pasien. Menerapkan The SBAR Tools dalam kegiatan dan aktivitas seluruh unit serta perlu adanya sosialisasi dan pengenalan tentang patient safety kepada seluruh karyawan secara periodik sehingga pendeklarasian budaya safety tetap menjadi prioritas dalam pelayanan. Adanya reward and punishment yang tertulis dalam pelaksanaan program keselamatan pasien di rumah sakit.

\section{DAFTAR PUSTAKA}

Beckett, C.D. \& Kipnis, G, 2009. Collaborative communication: integrating SBAR to improve quality/patient safety outcomes. Journal for healthcare quality: official publication of the National Association for Healthcare Quality, 31(5), pp.19-28.
Brenant T. A., Leape.L.L., Laird. N, 1991, Incident of adverse event and negligence in hospitalized patients: result of the Harvard Medical Practice Study. New England Journal of Medicine, 324(6): 370-7.

Campion, M.A., Papper, E.M., \& Medsker, G.J, 1996, Relations between work team characteristics and

Chassin, Mark R, Galvin, Robert W, and the National Roundtable on Health Care Quality, 1998, Urgent Need to Improve Health Care Quality. JAMA, 280 (11):1000-1005.

Creswel, J.W.\& Plano Clark, V.L, 2007, Designing and Conducting Mixed Methods Research. United States of America: Sage Publications effectiveness: A replication and extension. Personnel Psychology, 49, 429-452.

Gardner, A. Hase, S., Gardner, G., Dunn, S.V, 2008, From competence to capability: a study of nurse practitioners in clinical practice. Journal of clinical nursing, 17(2), pp.250-8.

Ginsburg, L.R., Chuang.Y., Berta,W.B., Norton,P.G., Tregunno.D., Richardson.J, 2010, The relationship between organizational leadership for safety and learning from patient safety events. Health services research, 45(3), pp.60732.

Gurganious, B.V. \& Starke, S., 2009, Using Relationship Marketing To Grow Your Specialty Practice. Starke, (August).

Guzzo, R.A., Salas, E., \& Associates, 1995, Team effectiveness and decision-making in organizations. San Francisco: Jossey-Bass.

Hermina,. P, 2010, Penyusunan Leadership Competency Manajer di Rumah Sakit Bethesda, Tesis. MMR UGM, Yogyakarta

Institute of Medicine, 2000, Crossing the Quality Chasm, A new Health System for the $21^{\text {th }}$ Century, National Academy Press, Washington DC.

Jahrami, H., Marnoch, G. \& Gray, A.M, 2008, Leadership competencies in the context of health services. Health services management research: an official journal of the Association of University Programs in Health Administration / HSMC, AUPHA, 21(2), pp.117-30.

Kohn, Linda T., Corrigan, Janet $\mathrm{M}$ and Donalson, Molla S, 2000, To err is Human, Buliding a Safer Health System, Nasional Academy Press, Wachington, D.C.

Kristiani, S, 2006, Insentif dan Kepuasan Kerja Karyawan Dinas Kesehatan Propinsi Papua. 
Working Paper Series No (15). KMPK. Universitas Gadjah Mada, Yokyakarta.

Graham, I.W., Jack, E. \& Graham, I., 2008, Promoting leadership : the development of a nurse executive team in an acute hospital trust. Nursing, 1966 (DoH 2004), pp.955-963.

Miller, K. Riley W, Davis T, 2009, Identifying key nursing and team behaviours to achieve high reliability. Journal of Nursing Mangement, pp.247-255.

Nawawi.,H \& Hadari.,M, 2006, Kepemimpinan yang Efektif, Cetakan kelima. Penerbit Gadjah Mada University Press. Yogyakarta.
Ratto, M., Propper, C. \& Burgess, S., 2002. Using financial incentives to promote teamwork in health care. Journal of health services research \& policy, 7(2), pp.69-70.

Sahin, G.B, 2005, An Evaluation of the Leadership Attitudes of Managers in Turkish Armed Forces ' Hospitals. Military Medicine. 170.

Simamora, B, 2001, Remarketing For Business Recovery, Sebuah Pendekatan Riset. Penerbit PT Gramedia Pustaka Utama, Jakarta.

Wessel,J and Malin, S, 1997, Impact of leadership Development and Competences.Nursing Economic, Vol15. No 05,. pp 235-241.pdf. 